\title{
OUTDOOR LEARNING SEBAGAI METODE PEMBELAJARAN IPS DALAM MENUMBUHKAN KARAKTER PEDULI LINGKUNGAN
}

\author{
Jakiatin Nisa \\ Universitas Islam Negeri (UIN) Syarif Hidayatullah Jakarta \\ Email: jakiatin.nisa@uinjkt.ac.id \\ Naskah diterima : 3 Maret 2015, direvisi : 5 April 2015, disetujui : 16 April 2015
}

\begin{abstract}
The world is increasingly rapid growth affect the level of competitiveness of each country in all sectors to conduct rapid national development and sustainable. However, the exploitation of the resources to open up the economy through infrastructure development, many did not heed the ability and capacity of the environment. Human resources play an important role in the process of success in maintaining, maintaining quality and environmental sustainability. Education is the most important element in the development system that can produce quality buman resources. Through education (learning) that can foster environmentally conscious character, developing the potential of individuals (students) to be able to understand the importance of preserving the environment can be realized.
\end{abstract}

Keywords: carrying capacity of the environment; education; care for the environment character

\section{Abstrak}

Pertumbuhan dunia yang semakin pesat mempengaruhi tingkat daya saing setiap negara di segala bidang untuk melakukan pembangunan nasional secara cepat dan berkesinambungan. Namun, eksploitasi sumber-sumber daya untuk membuka perekonomian melalui pembangunan infrastruktur banyak yang tidak mengindahkan kemampuan dan daya dukung lingkungan. Sumber daya manusia memegang peranan penting dalam proses keberhasilan dalam menjaga, mempertahankan kualitas dan kelestarian lingkungan. Pendidikan menjadi unsur terpenting dalam sistem pembangunan yang dapat menghasilkan sumber daya manusia yang berkualitas. Melalui pendidikan (pembelajaran) yang mampu menumbuhkan karakter peduli lingkungan, pengembangan potensi individu (peserta didik) untuk mampu memahami pentingnya melestarikan lingkungan dapat terwujud.

Kata kunci: daya dukung lingkungan; pendidikan; karakter peduli lingkungan

Pengutipan: Nisa, J. (2015). Outdoor Learning sebagai Metode Pembelajaran IPS dalam Menumbuhkan Karakter Peduli Lingkungan. SOSIO DIDAKTIKA: Social Science Education Journal, 2(1), 2015, 1-11. doi:10.15408/sd.v2i1.1339.

Permalink/DOI: http://dx.doi.org/10.15408/sd.v2i1.1339 


\section{A. Pendahuluan}

Lajupertumbuhan dunia yang semakin tinggi mempengaruhi tingkat daya saing setiap negara di segala bidang untuk melakukan pembangunan nasional secara pesat dan berkesinambungan (sustainable development). Kemampuan negara untuk menjalankan pembangunan secara keseluruhan akan menentukan posisinya di kancah dunia internasional.

Sejarah dimulainya pembangunan modern dimulai pada tahun 1800 di Amerika Serikat. Saat itu merupakan masa eksploitasi sumbersumber daya dan membuka perekonomian yang ditandai dengan pembangunan infrastruktur transportasi dan kanal air. Jepang memulai pembangunannya menjelang tahun 1900, yang ditandai dengan era keterbukaan Jepang terhadap pengaruh-pengaruh peradaban asing untuk mendorong modernisasi ketatanegaraan dan militer. Pembangunan Indonesia dimulai secara efektif menjelang tahun 1970, yang ditandai oleh paradigma pembangunan ekonomi yang terencana. ${ }^{1}$

Pembangunan sebagai salah satu dampak dari modernisasi bagi Indonesia menjadi tantangan yang serius. Diperlukan ide baru untuk mampu menyelesaikan permasalahan internal yang datang silih berganti, dari permasalahan bidang ekonomi, sosial, budaya, pendidikan bahkan permasalahan tentang lingkungan (pembangunan berkelanjutan/ sustainable development).

Pembangunan didefinisikan Sudarja sebagai "upaya suatu bangsa untuk meningkatkan mutu dengan memanfaatkan sumber daya yang ada, baik sumber daya manusia maupun sumber daya alam melalui proses perencanaan, pelaksanaan dan evaluasi yang berkelanjutan"'. Dari definisi itu disebutkan bahwa untuk pembangunan suatu negara diperlukan sumber daya, baik alam maupun manusia yang memahami tentang proses perencanaan, pelaksanaan dan evaluasi yang berkelanjutan sesuai dengan kemampuan dan daya dukung lingkungan. Namun pada kenyataannya eksploitasi sumberdaya alam banyak tidak mengindahkan kemampuan dan daya dukung lingkungan yang akhirnya

\footnotetext{
1 Iwan Nugroho dan Rakhmin Dahuri, Pembangunan Wilayah Perspektif Ekonomi, Sosial dan Lingkeungan, (Jakarta: LP3ES, 2012), h. 85.

2 Adiwikarta Sudarja, Catatan Perkuliaban Etika PLS dalam Pembangunan, (Bandung: PPS UPI, 2005), h. 1.
}

mengakibatkan merosotnya kualitas lingkungan. Tidak menunggu waktu terlalu lama, dampak dari kemerosotan kualitas lingkungan hidup semakin nyata terasa dan terlihat. Seperti halnya salah satu kasus kejahatan lingkungan di Jawa Barat pada Tahun 2014 yang dilaporkan BPLHD terkait dua pabrik tekstil di wilyah timur yang diketahui membuang limbah secara langsung ke daerah aliran sungai Citarum tanpa melalui pengolahan yang mengakibatkan pencemaran air sungai yang sangat merugikan masyarakat sekitar sungai. $^{3}$

Sumber daya manusia memegang peranan penting dalam proses keberhasilan dalam menjaga dan mempertahankan kualitas dan kelestarian lingkungan. Sumber daya manusia yang berkualitas sangat dibutuhkan dalam mewujudkan manusia Indonesia seutuhnya yang mampu menghadapi tantangan pembangunan.

Pendidikan merupakan salah satu komponen terpenting dalam sistem pembangunan yang dapat menghasilkan sumber daya manusia yang berkualitas. Melalui pendidikan pengembangan potensi individu untuk mengembangkan kecakapan dalam mengambil keputusan yang tepat, yang mampu menumbuhkan karakter peduli lingkungan, pengembangan potensi individu (peserta didik) untuk mampu memahami pentingnya melestarikan lingkungan serta mampu berperan dalam pembangunan berkelanjutan dapat terwujud.

\section{B. Hakekat Outdoor learning}

Menurut Neill, beberapa peneliti mengambil falsafah Outdoor learning dari Outdoor Education berdasarkan doktrin dari Comenius, Rousseau, dan Pestalozzi, yang esensinya adalah sebagai berikut:

John Amos Comenius (1592-1670) was
a strong advocate of sensory learning who
believed that the child should experience the
actual object of study before reading about
it. He thought the use of the sense - seeing,
hearing, tasting, and touching - were the
avenues through which children were to come in
contact with the natural world. In preparation

BPLHD limpahkan kasus kejahatan lingkungan 2014 dalam http:// radarbandung.co.id/berita--bplhd-limpahkan-kasus-kejahatan-lingkungan-.html, diunduh pada 20 Januari 2015. 
for the later study of natural sciences, children should first gain acquaintance with objects such as water, earth, fire, rain, plants, and rocks. ${ }^{4}$

Comenius percaya bahwa peserta didik seharusnya belajar dari pengalaman hidup mereka langsung melalui lingkungan alam, sehingga mereka memilki perasaan, pandangan, pendengaran, citra rasa dan sentuhan yang langsung ke objek nyata, seperti air, tanah, api, hujan, tumbuhan, bebatuan dan sebagainya.

Jean-Jacques Rousseau (1712-1778) carried
out the ideas of Comenius by educating the boy,
Emile, according to principles found in nature.
He believed that physical activity was very
important in the education of a child. They are
curious, he claimed, and this curiosity should
be ultilized to the fullest. Roussean preached
that education should be more sensory and
rational; less literary and linguistic. Rather
than learning indirectly from books, children
should learn through direct experience. He
proclaimed, "Our first teachers are our feet,
our hands and our eyes. To substitute books for
all these...is but to teach us to use the reasons
of others."

Rousseau menekankan bahwa aktivitas fisik di luar ruangan sangat penting di dalam pembelajaran. Untuk memenuhi keingintahuan dan tuntutan peserta didik, seharusnya pendidikan lebih ditekankan pada pengalaman yang berhubungan dengan alat pancaindera dan rasional daripada buku-buku teks/buku paket pelajaran. Rousseau menyatakan bahwa guru pertama dalam kehidupan manusia adalah kaki, tangan dan mata.

Johann Henrick Pestalozzi (1746-1827)
emphasized the use of direct, firsthand
experiences and real objects, also. Pestalozzi,
a follower of Rousseau, urged teachers to take
their pupils out of the classroom: Lead your
child out into nature, teach bim on the hilltops
and in the valleys. There be will listen better,
and the sense of freedom will given him more
strength to overcome difficulties. But in these
bours of freedom let him be taught by nature
rather than by you. Let him fully realize that

4 James Neill, C: $\backslash$ Documents and Settings $\backslash W$ indow₹ $X P \backslash M y$ Documents $\backslash$ Philoso phy of Outdoor Education.htm Com/psycho-evolutionary/SocioCulturalHistory Outdoor Education, (2006 d).html

5 James Neill, A Socio-cultural History of Outdoor Education. http:// wilder dom. (2004 a) html she is the real teacher and that you, with your art, do nothing more than walk quietly at her side.

Demikian halnya dengan Pestalozzi, Pengalaman langsung dengan obyek nyata merupakan pelajaran permulaan bagi peserta didik. Para guru harus membawa peserta didik ke luar dari ruangan kelas, ke perbukitan, lembahlembah, sungai, pasar ataupun pabrik. Para guru harus membiarkan alam dan lingkungan sekitar peserta didik yang mendidik peserta didik lebih daripada kata-katanya. Pengalaman yang penting ini, merupakan persiapan dasar pengetahuan yang lebih lanjut dan mempersiapkan mental peserta didik untuk menghadapi berbagai kesulitan di kemudian hari. Menurut White dalam terjemahan Pasuhuk, dkk. "Bagi anak kecil, yang belum sanggup untuk belajar dari halaman yang tertulis atau belum diperkenalkan dengan cara tetap di dalam ruang kelas, alam dan lingkungan sekitar memberikan sumber pengajaran dan kegembiraan yang tidak akan gagal." Selanjutnya dikatakan White, "Hubungan tetap dengan rahasia kehidupan dan keindahan alam, ... cenderung untuk menguatkan pikiran dan menghaluskan serta mengangkat tabiat." Pada bagian lain dikatakan White, "Semakin tenang dan sederhana kehidupan seorang anak-semakin bebas dari kemeriahan semu dan semakin berada dalam keharmonisan dengan alam semakin menguntungkan untuk kesegaran fisik dan mental serta kekuatan rohani."

Outdoor learning akan memberikan dampak yang positif bagi peserta didik diantaranya adalah: sikap, kepercayaan dan persepsi diri yang lebih baik. Outdoor learning dapat meningkatkan keterampilan sosial, kerjasama, dan komunikasi yang lebih baik. Selain itu kemampuan akademik peserta didik dan kesadaran lingkungan menjadi lebih baik. Selain itu Outdoor learning mendukung untuk kesehatan dan pertumbuhan peserta didik karena fisik peserta didik terlibat aktif dan bebas bergerak, meningkatkan kepercayaan diri peserta didik, memberi kesempatan lebih luas bagi peserta didik untuk berkomunikasi dengan orang lain, meningkatkan keaktifan peserta didik di dalam belajar. Outdoor learning juga mengembangkan peserta didik untuk belajar

6 Ellen G. White, Education (Membina Pendidikan Sejati), Buku diterjemahkan oleh Pasuhuk, (Bandung-Indonesia, Publishing House Bandung: Indonesia, 2005), h.88

7 Ibid., h. 96,100 
keamanan dan pemantauan karena belajar dalam situasi yang baru dan resiko yang lebih tinggi, mengembangkan kreatifitas dan kemampuan menyelesaikan masalah, meningkatkan daya imajinasi, penemuan dan kemampuan nalar peserta didik. Pembelajaran Outdoor learning akan memberikan kesempatan peserta didik untuk kontak langsung dengan dunia nyata dan memberi suatu pengalaman yang unik yang tidak ditemukan di dalam kelas atau secara textbook.

Ciri dari Outdoor learning adalah adanya kegiatan eksplorasi melalui proses discovery dan inquiry, sementaraitu obyek yang dipelajari adalah lingkungan sekitar peserta didik. Pembelajaran Outdoor learning ini mengajak peserta didik aktif mengeksplorasi lingkungan sekitarnya untuk mencapai kecakapan kognitif, afektif, dan psikomotornya sehingga memiliki penguasaan ilmu dan keterampilan. Ciri kedua adalah selalu ada kegiatan berupa peramalan (prediksi), pengamatan, dan penjelasan. Ciri ketiga adalah ada laporan untuk dikomunikasikan baik secara lisan, tulisan, gambar, foto atau audiovisual. Ciri keempat kegiatan pembelajarannya dirancang menyenangkan sehingga menimbulkan minat untuk belajar lebih lanjut.

\section{Hakekat Nilai Karakter Peduli Lingkungan}

Menurut Althof dan Berkowits pemahaman tentang pendidikan karakter menjadi bahasan kontemporer yang cukup sulit untuk didefinisikan, karena mencakup pendekatan yang sangat luas dengan target tujuan, strategis pedagogis, dan orientasi filosofis. ${ }^{8}$ Althof dan Berkowits mengidentifikasi perbedaan pendidikan moral dan pendidikan karakter. Pendidikan moral fokus pengajarannya pada pengembangan penalaran rasa keadilan dan moralitas terhadap kepedulian antar individu. Fokus pengajaran pendidikan karakter pada pengembangan karakter dari dalam (rohani) dan pengembangan karakter dari luar (jasmani) individu. ${ }^{9}$

Menurut Majid dan Andayani asal karakter berasal dari bahasa Latin kharakter, kharassein, dan kharax yang maknanya "tools for marking",

\footnotetext{
8 Althof, W and Berkowits, MW, "Moral Education and Character Education: Tear Realationship and Roles in Citizenship Education", dalam Journal o Moral Education, 35 (4), 2006, h. 498.

9 Ibid, h. 499.
}

"to engrave", dan "pointed stake"10. Kata ini mulai banyak digunakan (kembali) dalam bahasa Perancis caractere pada abad ke-14 dan kemudian masuk dalam bahasa Inggris menjadi character, sebelum akhirnya menjadi bahasa Indonesia karakter. Sedangkan menurut Budimansyah inti karakter adalah kebajikan (goodness), dalam arti berpikir baik (thinking good), berperasaan baik (telling good) dan berperilaku baik (behaving good). ${ }^{11}$

Beberapa pengertian pendidikan karakter yang lain di antaranya adalah, menurut Koesoema yang menyatakan bahwa pendidikan karakter adalah keseluruhan dinamika relasional antara pribadi dengan berbagai macam dimensi, baik dari dalam maupun dari luar dirinya, agar pribadi tersebut semakin dapat menghayati kebebasan sehingga dapat bertanggung jawab atas pertumbuhan dirinya sendiri sebagai pribadi dan perkembangan orang lain dalam hidup mereka. ${ }^{12}$

Menurut Sudirman, dkk. Pendidikan karakter adalah suatu sistem penanaman nilai-nilai perilaku (karakter) kepada warga sekolah atau kampus yang meliputi kompenen pengetahuan, kesadaran atau kemauan dan tindakan untuk melaksanakan nilai-nilai tersebut, baik terhadap Tuhan Yang Maha Esa, diri sendiri, sesama lingkungan maupun kebangsaan sehingga menjadi paripurna (insan kami $).{ }^{13}$ Pendidikan karakter adalah suatu usaha yang menyeluruh agar orang-orang memahami, peduli, berperilaku sesuai nilai-nilai etika dasar, dengan demikian objek dari pendidikan karakter adalah nilai-nilai.

Dalam bukunya Zuchdi, Nilai-nilai ini dapat melalui proses internalisasi dari apa yang diketahui, yang membutuhkan waktu sehingga terbentuklah pekerti yang baik sesuai dengan nilai yang ditanamkan. Nilai-nilai ini adalah nilai-nilai hidup yang merupakan realitas yang ada di dalam masyarakat. ${ }^{14}$

\footnotetext{
10 Abdul Majid dan Dian Andavani, Pendidikan Karakter Perspektif Islam, (Bandung: PT. Remaja Rosda Karya, 2012), h. 11.

11 Dasim Budimansyah, Penguatan Pendidikan Kewarganegaraan untuke Membangun Karakter Bangsa, (Bandung: Widya Aksara Press, 2010), h. 54.

12 Doni Koesoema, Pendidikan Karakter : Kajian Teori dan Praktik, di Sekolah, (Bandung: Remaja Rosdakarya, 2011), h. 123.

13 Sudirman dkk, Buku Panduan Mata Kuliah Pendidikan Karakter, (Yogyakarta: Fakultas Ilmu Sosial dan Ekonomi UNY, 2010), h. 2

14 Darmiyati Zuchdi, Pendidikan karakter dalam prespektif teori dan praktik, (Yogyakarta: UNY Press, 2011), h. 3.
} 
Pendidikan karakter dapat dimaknai sebagai "the deliberate use of all dimensions of school life to foster optimal character development”. Dalam pendidikan karakter di sekolah, semua komponen (pemangku pendidikan) harus dilibatkan, termasuk komponen-komponen pendidikan itu sendiri, yaitu isi kurikulum, proses pembelajaran dan penilaian, penanganan atau pengelolaan mata pelajaran, pengelolaan sekolah, pelaksanaan aktivitas, pemberdayaan sarana prasarana, pembiayaan, dan etos kerja seluruh warga sekolah atau lingkungan. Pendidikan karakter dimaknai sebagai suatu perilaku warga sekolah yang dalam menyelenggarakan pendidikan harus berkarakter.

Menurut Zamroni dalam Zuchdi pendidikan karakter merupakan proses untuk mengembangkan pada diri setiap peserta didik kesadaran sebagai warga bangsa yang bermartabat, merdeka, dan berdaulat serta berkemauan untuk menjaga dan mempertahankan kemerdekaan dan kedaulatan tersebut.

Menurut Suhady dan Sinaga character building adalah suatu proses atau usaha yang dilakukan untuk membina, memperbaiki, dan atau usaha membentuk tabiat, watak, sifat-sifat kejiwaan, akhlak (budi pekerti), insan manusia (masyarakat) sehingga menunjukkan perangai dan tingkah laku yang baik berlandaskan nilainilai Pancasila. ${ }^{15}$

Nilai-nilai pembentuk karakter yang bersumber dari agama, pancasila, budaya dan tujuan pendidikan nasional ${ }^{16}$ (Pusat Kurikulum, Pengembangan dan Pendidikan Budaya \& Karakter Bangsa: Pedoman Sekolah, yaitu:

1. Religius: Sikap dan perilaku yang patuh dalam melaksanakan ajaran agama yang dianutnya, toleran terhadap pelaksanaan ibadah agama lain, dan hidup rukun dengan pemeluk agama lain.

2. Jujur: Perilaku yang dilaksanakan pada upaya menjadikan dirinya sebagai orang yang dapat dipercaya dalam perkataan, tindakan dan pekerjaan.

3. Toleransi: Sikap dan tindakan yang

15 Idup Suhady dan A. M. Sinaga, Wawasan Kebangsaan dalam Kerangka Negara Kesatuan Republik Indonesia, (Jakarta: Lembaga Administrasi Negara, 2006), h. 59

16 Pusat Kurikulum, Pengembangan dan Pendidikan Budava \& Karakter Bangsa: Pedoman Sekolah. (Jakarta: Puskur, 2009), hal. 9-10 menghargai perbedaan agama, suku, etnis, pendapat sikap dan tindakan orang lain yang berbeda dari dirinya.

4. Disiplin: Tindakan yang menunjukkan perilaku tertib dan patuh pada berbagai ketentuan dan peraturan.

5. Kerja keras: Perilaku yang menunjukkan upaya sungguh-sungguh dalam mengatasi berbagai hambatan dan tugas, serta menyelesaikan tugas dengan sebaikbaiknya.

6. Kreatif: Berpikir dan melakukan sesuatu untuk menghasilkan cara atau hasil baru dari sesuatu yang telah dimiliki.

7. Mandiri: Sikap dan perilaku yang tidak mudah tergantung pada orang lain dalam menyelesaikan tugas-tugas.

8. Demokratis: Cara berpikir, bersikap dan bertindak yang menilai sama hak dan kewajiban dirinya dan orang lain.

9. Rasa ingin tahu: Sikap dan tindakan yang selalu berupaya untuk mengetahui lebih mendalam dan meluas dari sesuatu yang dipelajarinya, dilihat dan didengar.

10. Semangat kebangsaan: Cara berpikir, bertindak dan berwawasan yang menempatkan kepentingan bangsa dan negara di atas kepentingan diri dan kelompoknya.

11. Cinta tanah air: Cara berpikir, bersikap dan berbuat yang menunjukkan kesetiaan, kepedulian dan penghargaan yang tinggi terhadap bahasa, lingkungan fisik, sosial, budaya, ekonomi, dan politik bangsa.

12. Menghargai prestasi: Sikap dan tindakan yang mendorong dirinya untuk menghasilkan sesuai yang berguna bagi masyarakat dan mengakui, serta menghormati keberhasilan orang lain.

13. Bersahabat atau komunikatif: Tindakan yang memperhatikan rasa senang berbicara, bergaul dan bekerja sama dengan orang lain.

14. Cinta damai: Sikap, perkataan dan tindakan yang menyebabkan orang lain merasa senang dan aman atas kehadiran dirinya. 
15. Gemar membaca: Kebiasaan menyediakan waktu untuk membaca berbagai bacaan yang memberikan kebajikan pada dirinya.

16. Peduli lingkungan: Sikap dan tindakan yang selalu berupaya mencegah kerusakan pada lingkungan alam di sekitarnya, dan mengembangkan upaya-upaya untuk memperbaiki kerusakan alam yang sudah terjadi.

17. Peduli sosial: Sikap dan tindakan yang selalu ingin memberikan bantuan pada orang lain dan masyarakat yang membutuhkan.

18. Tanggung jawab: Sikap dan perilaku seseorang untuk melaksanakan tugas dan kewajibannya, yang seharusnya dia lakukan, terhadap diri sendiri, masyarakat, lingkungan (alam, sosial dan budaya), negara dan Tuhan Yang Maha Esa.

Sedangkan berdasarkan kajian berbagai nilai agama, norma sosial, peraturan atau hukum, etika akademik, dan prinsip-prinsip hak asasi manusia, menurut Samani dan Hariyanto telah teridentifikasi butir-butir nilai yang dikelompokkan menjadi lima nilai utama ${ }^{17}$ yaitu:

1. Nilai karakter dalam hubungannya dengan Tuhan yaitu religius.

2. Nilai karakter hubungannya dengan diri sendiri yaitu : jujur, bertanggung jawab terhadap diri sendiri, masyarakat dan lingkungannya, bergaya hidup sehat, disiplin, kerja keras, percaya diri, berjiwa wirausaha, berpikir logis, kritis, kreatif dan inovatif, mandiri, ingin tahu, cinta ilmu.

3. Nilai karakter hubungannya dengan sesama yaitu sadar hak dan kewajiban diri dan orang lain, patuh pada aturan-aturan sosial, menghargai karya dan prestasi orang lain, santun, demokratis.

4. Nilai karakter hubungannya dengan lingkungan yaitu kepedulian terhadap sosial dan lingkungan.

5. Nilai kebangsaan yaitu nasionalis dan menghargai keberagaman. Keberhasilan penciptaan nilai-nilai karakter di atas, tentunya tidak hanya terletak pada satu pihak, tetapi ada beberapa pihak yang ikut

17 Muchlas Samani dan Hariyanto, Konsep dan Model Pendidikan Karakter, (Bandung : PT Remaja Rosda Karya, 2011), h. 29. berperan.

Penanaman nilai karakter merupakan keseluruhan proses pendidikan yang dialami peserta didik sebagai pengalaman pembentukan kepribadian melalui memahami dan mengalami sendiri nilai-nilai tersebut. Karakter peduli lingkungan yaitu suatu sikap yang dimiliki seseorang untuk memperbaiki dan mengelola lingkungan secara benar dan bermanfaat sehingga dapat dinikmati secara terus menerus tanpa merusak keadaannya, turut menjaga dan melestarikan sehingga ada manfaat yang berkesinambungan.

Manusia termasuk dalam lingkungan hidup dan perilakunya juga mempengaruhi kelangsungan bagi kehidupan dan kesejahteraan makhluk lainnya. Jadi nilai karakter yang berhubungan dengan lingkungan hidup perlu dikembangkan agar manusia peduli dengan lingkungan. Hal ini dapat ditempuh dengan menjaga dan melestarikan lingkungan hidup. Seperti yang dituliskan dalam Husein bahwa melalui pendidikan, latihan, penerangan dan penyuluhan wawasan baru serta kesadaran lingkungan hidup dan pembangunan berkelanjutan harus ditingkatkan terusmenerus. ${ }^{18}$

Nilai karakter yang berhubungan dengan lingkungan hidup adalah peduli lingkungan. Keraf menyampaikan dalam bukunya, peduli lingkungan adalah sikap dan tindakan yang selalu berupaya mencegah kerusakan lingkungan alam di sekitarnya dan mengembangkan upaya-upaya untuk memperbaiki kerusakan alam yang telah terjadi. $^{19}$

Kesadaran dan kepedulian manusia terhadap lingkungan tidak dapat tumbuh begitu saja secara alamiah, namun harus diupayakan pembentukannya secara terus menerus sejak usia dini, melalui kegiatan-kegiatan nyata yang dekat dengan kehidupan sehari-hari. Langkah yang paling strategis untuk menanamkan kesadaran terhadap lingkungan hidup adalah melalui pendidikan, baik pendidikan formal atau pendidikan non-formal.

Tujuan pendidikan karakter peduli lingkungan adalah: 1) Mendorong kebiasaan dan

\footnotetext{
18 M. Husein Harun, Berbagai Aspek Hukum Analisis Mengenai Dampak Lingkungan, (Jakarta: Bumi Aksara, 1992), h. 277.

19 Keraf, Sony, Etika Lingkungan, (Jakarta: Penerbit Buku Kompas, 2010), h. 166-184.
} 
perilaku peserta didik yang terpuji dan sejalan dengan pengelolaan lingkungan yang benar; 2) Meningkatkan kemampuan untuk menghindari sifat-sifat yang dapat merusak lingkungan; 3) Memupuk kepekaan peserta didik terhadap kondisi lingkungan sehingga dapat menghindari sifat-sifat yang dapat merusak lingkungan; 4) Menanamkan jiwa peduli dan bertanggung jawab terhadap kelestarian lingkungan.

Menurut Azwar dalam Faizah dkk, Sikap peduli lingkungan merupakan sikap saling berinteraksi dalam memahami, merasakan dan berperilaku terhadap suatu obyek. Sebagai makhluk sosial, manusia tidak dapat lepas dari lingkungan. Sikap peduli lingkungan yaitu sikap positif dalam menjaga dan mempertahankan kualitas lingkungan ${ }^{20}$. Perilaku peduli lingkungan adalah kemampuan untuk membuat pilihan tentang bagaimana bersikap merespon berdasarkan dan kelestarian lingkungan. Impuls dorongan hati. Perilaku peduli lingkungan berdasarkan pada prinsip-prinsip etika lingkungan, dan prinsip etika lingkungan yang diterapkan dalam pembelajaran IPS yaitu: (1) sikap hormat terhadap lingkungan, (2) prinsip tanggung jawab, (3) prinsip solidaritas, (4) prinsip kasih sayang, (5) prinsip tidak merusak, (6) prinsip hidup sederhana dan selaras dengan alam, (7) prinsip keadilan, (8) prinsip demokrasi, dan (9) prinsip integritas moral.

\section{Menumbuhkan Karakter Peduli Lingkungan dalam Pembelajaran IPS}

Proses pembelajaran menjadi sangat penting dalam menumbuhkan nilai karakter peduli lingkungan. Berdasarkan hasil penelitian Cross (1983) dan Robenson (1977) di Lowa dan California, mencatat bahwa penghargaan terhadap proses dan hasil pembelajaran, menciptakan lingkungan yang mendukung orientasi faktor sosiobudaya dan geografi, dan keberadaan kondisi kependudukan dapat mendatangkan sikap yang positif bagi peserta didik. Hal ini sejalan dengan salah satu tujuan kurikulum IPS menurut Sumaatmadja yaitu harus mampu membekali peserta didik dengan kesadaran, sikap mental yang positif dan keterampilan ter-

20 Hadi Faizah, P. Sudharto P, dan Syafrudin, 'Pengelolaan Sampah Rumah Tangga Berbasis Mayarakat (Studi Kasus di Kota Yogyakarta)", dalam http:/ /eprints.undip.ac.id/17210/ di akses pada 3 April 2015 hadap lingkungan hidup yang menjadi bagian dari kehidupannya yang tidak terpisahkan. ${ }^{21}$ Sehingga pembelajaran yang bermakna bukan sekedar penyampaian materi dan untuk mengejar pencapaian-pencapaian kurikulum dan mengembangkan kemampuan semata. Pembelajaran yang bermakna seharusnya tidak seperti yang terjadi pada beberapa sekolah dalam pembelajaran IPS, Utami Munandar (1990) dalam Al Muchtar, memberikan penilaian terhadap perolehan pendidikan dewasa ini, bahwa kelemahan utama pendidikan adalah terlalu besarnya penekanan terhadap aspek kognitif. Hal ini pun terjadi pada mata pelajaran IPS. ${ }^{22}$

Pembelajaran IPS harus berfungsi untuk membentuk karakter dan peradaban bangsa yang bermartabat. Dari hal ini maka sebenarnya dalam pembelajaran harus menumbuhkan karakter termasuk karakter peduli lingkungan yang tidak bisa ditinggalkan dalam berfungsinya pendidikan. Oleh karena itu, sebagai fungsi yang melekat pada keberadaan pendidikan nasional untuk membentuk watak dan peradaban bangsa, menumbuhkan karakter merupakan manifestasi dari peran tersebut. Untuk itu, menumbuhkan karakter menjadi tugas dari semua pihak yang terlibat dalam usaha pendidikan (pendidik).

Menumbuhkan karakter peduli lingkungan dalam pembelajaran IPS bisa melalui penerapan metode pembelajaran. Metode pembelajaran merupakan cara yang dipergunakan guru dalam mengadakan hubungan dengan peserta didik pada saat berlangsungnya pembelajaran. Metode pembelajaran sangat diharapkan dapat membangun interaksi antara guru dengan para peserta didik dan mempertajam lingkungan/ suasana saat proses pembelajaran, sehingga beberapa praktik dalam penerapan metode pembelajaran menjadi sasaran kajian formal, diteliti dan dimanipulasi/dipoles sehingga menjadi metode yang dapat digunakan dalam mengembangkan keterampilan-keterampilan profesional untuk tugas-tugas pembelajaran.

Bagi sebagian guru, konsep tentang berbagai metode pembelajaran merupakan jalan besar untuk mempertahankan profesionalitas. Dalam satu kesimpulan yang muncul dalam

\footnotetext{
21 Nursid Sumaatmadja, Metodologi Pengajaran Ilmu Pengetabuan Sosial (IPS), (Bandung: Alumni, 1984), h. 48.

22 S. Al Muchtar, Pengembangan Berpikir dan Nilai dalam Pendidikan IPS. (Bandung: Gelar Pustaka Mandiri, 2006), h. 61.
} 
penelitian Bruce (1970-1980) dalam Joyce, Weil dan Calhoun bahwa ada begitu banyak metode pembelajaran, sebagian ada yang hanya bisa diterapkan untuk satu atau dua tujuan, sebagian lagi ada yang bisa diterapkan untuk tujuan yang lebih besar, dan sebagian yang lain ada yang benarbenar sesuai untuk tujuan-tujuan tertentu. ${ }^{23}$ Tanggung jawab guru sebagai seorang pendidik adalah untuk mencapai belajar dan mengajar, dan beberapa guru hanya berfokus pada satu pencapaian itu saja. Dengan memberikan aspek pengajaran dan seolah meninggalkannya peserta didik untuk belajar tanpa arti/tidak meaningful. Guru sangat jarang memberikan pengalaman belajar yang membuat dampak penting pada diri peserta didiknya. Padahal banyak para ahli yang menyatakan bahwa setiap peristiwa akan memberikan pengalaman yang akan memberikan pengaruh pada kehidupan seseorang. Peristiwa dan hasil dari setiap peristiwa dapat bervariasi, tetapi perasaan dari pengalaman-pengalaman tampaknya memiliki kesamaan yang tak terkatakan bahwa banyak dapat menggambarkan sebagai pengalaman yang berarti.

Dalam pembelajaran IPS, guru dapat menggunakan metode pembelajaran yang sesuai dengan tema materi pelajaran IPS. Metode Outdoor learning salah satunya sebagai metode yang mampu memperkenalkan lingkungan sekitar peserta didik baik sebagai media maupun sumber belajar pembelajaran IPS, melalui Outdoor learning lah peserta didik akan memahami makna lingkungan sebagai sumber belajar IPS sekaligus sebagai jalan memperkenalkan arti penting dari suatu kelestarian pada lingkungan, menjadi jalan untuk meningkatkan kapasitas belajar peserta didik dan menjadikan peserta didik lebih memahami objek-objek yang dihadapi dari pada jika belajar di dalam kelas yang memiliki banyak keterbatasan. Lebih lanjut, belajar di luar kelas dapat menolong peserta didik untuk mengaplikasikan pengetahuan yang dimiliki. Selain itu, pembelajaran di luar kelas lebih menantang bagi peserta didik dan menjembatani antara teori di dalam buku dan kenyataan yang ada di lapangan. Kualitas pembelajaran dalam situasi yang nyata akan memberikan peningkatan kapasitas pencapaian

23 Joyce, B., Weil, M., dan Calhoun, E, Models Of Teacbing, (Yogyakarta: Pustaka Pelajar, 2009), h. 30. belajar melalui objek yang dipelajari serta dapat menumbuhkan nilai karakter peduli lingkungan.

Pembelajaran IPS melalui Outdoor learning, berdasar falsafah dan hakekatnya di atas, dapat menjadikan peserta didik mengenal obyek, mengenal gejala dan permasalahannya, serta menelaah dan menemukan kesimpulan atau konsep tentang hal yang dipelajari. Kegiatan belajar Outdoor learning akan mendorong peserta didik untuk melakukan berbagai tindakan yang akan memberikan pengalaman langsung dan konkrit bagi mereka. ${ }^{24}$ Kegiatan belajar melalui Outdoor learning akan memberi peluang lebih luas kepada peserta didik, untuk mempelajari obyek-obyek dalam mata pelajaran IPS yang menjadi pusat perhatiannya, atau yang lebih sesuai dengan kebutuhan setiap peserta didik dan memahami konsep peduli lingkungan.

Beberapa nilai karakter peduli lingkungan yang dapat diterapkan dalam pembelajaran IPS melalui Outdoorlearning adalah pemahaman terkait konsep peduli lingkungan yang diintegrasikan pada materi yang akan disampaikan saat outdoor learning berlangsung, misalnya, selalu menghubungkan materi dengan konsep karakter peduli lingkungan melalui penanaman nilai kebaikan/manfaat dari kelestarian lingkungan bagi kehidupan, salah satu contohnya dalam sub materi kelestarian lingkungan, menyampaikan fungsi pohon (sambil menunjuk salah satu pohon saat Outdoor learning berlangsung) adalah untuk menahan laju air. Jika banyak pohon seperti di hutan, akan mampu membuat lebih banyak air yang terserap ke dalam tanah $(60 \%$ $80 \%$ ). Dengan kemampuan ini, keberadaan pohon dapat meningkatkan cadangan air tanah, dan akar pohon akar pohon berfungsi sebagai penahan erosi tanah. Dengan memasukkan konsep fungsi pohon seperti di atas, diharapkan peserta didik memiliki kesadaran bahwa pohon memiliki nilai penting bagi lingkungan.

Hal lain yang bisa dilakukan melalui outdoor learning untuk menumbuhkan perilaku peduli lingkungan (yang menjadi bagian dari nilai karakter peduli lingkungan) dapat pula diawali dengan peran guru dalam memberikan keteladanan, guru dapat mencontohkan langsung (1) cara membuang sampah dengan

24 Yuni Wibowo, Bentuk-Bentuk Pembelajaran Outdoor, dalam http://staff.uny.ac.id/sites/default/files/tmp/Bentuk-bentuk $\% 20$ pembelajaran\%20outdoor.pdf., di akses 3 Maret 2015. 
baik dengan memisahkan sampah organik dengan anorganik, (2) memelihara tanaman (tidak merusak tanaman), (3) cara menghemat air dengan mencontohkan menyiram tanaman (4) menanam pohon di sekitar sekolah yang bisa diaplikasikan peserta didik di sekitar rumah masing-masing peserta didik.

Substansi terpenting adalah ada pada upaya pemahaman bahwa ada keterhubungan antara unsur fisik (lingkungan/alam) dengan manusia. Pemahaman bahwa peserta didik merupakan bagian dari anggota masyarakat modern yang mampu membuat keputusan yang luas jangkauannya di setiap harinya. Peserta didik menjadi paham bahwa setiap keputusan akan memberikan/memiliki dampak jauh melampaui waktu dan tempat di mana keputusan tersebut sedang dibuat. Seperti sebagai contoh, memutuskan untuk tidak membuang sampah ke sungai, adalah hasil pemahaman peserta didik akan dampak yang akan muncul jika membuang sampah ke sungai (akan terjadi banjir dengan meluapnya air sungai dan tercemarnya air sungai). Pengambilan keputusan untuk tidak membuang sampah ke sungai adalah sebuah pemahaman peduli lingkungan dan pemahaman akan keterhubungan antara unsur fisik (sungai) dengan manusia (perilaku membuang sampah). Begitupun keputusan-keputusan lainnya, seperti memelihara taman sekolah, bersepeda ke sekolah dan ataupun memutuskan untuk senantiasa menghemat dalam menggunakan air adalah bentuk tumbuhnya karakter peduli lingkungan.

\section{E. Penutup}

Berdasarkan pemaparan tersebut diperoleh beberapa kesimpulan. Pertama, Nilai Karakter Peduli lingkungan adalah nilai-nilai karakter yang berhubungan dengan pemahaman dan sikap peserta didik untuk memperbaiki dan mengelola lingkungan secara benar dan bermanfaat secara berkesinambungan.

Kedua, nilai karakter peduli lingkungan ini bisa diinternalisasikan dalam Pembelajaran IPS dengan salah satu metode Outdoor learning. Beberapa nilai karakter peduli lingkungan yang dapat diterapkan dalam pembelajaran IPS melalui Outdoorlearningadalah pemahaman terkait konsep peduli lingkungan yang diintegrasikan pada materi yang akan disampaikan saat outdoor learning berlangsung, selalu menghubungkan materi dengan konsep peduli lingkungan, melalui penanaman nilai kebaikan/manfaat dari kelestarian lingkungan bagi kehidupan.

\section{F. Daftar Pustaka}

Al Muchtar, S. (2004). Pengembangan Berpikir dan Nilai dalam Pendidikan IPS. Bandung: Gelar Pustaka Mandiri.

Althof, W and Berkowits, MW. (2006). "Moral Education and Character Education: Tear Realationship and Roles in Citizenship Education”. Journal o Moral Education. 35 (4).

Budimansyah, Dasim. (2010). Penguatan Pendidikan Kewarganegaraan untuk. Membangun Karakter Bangsa. Bandung: Widya Aksara Press.

Dimyati dan Mudjiono. (2006). Belajar dan Pembelajaran. Jakarta: PT. Rineke Cipta.

Giddens, Anthony. (1998). The Third Way Jalan Ketiga;Pembaharuan Demokrasi Sosial), Terj. Ketut Arya Mahardika, PT Gramedia Pustaka Utama, Jakarta, 2002.

Faizah, Hadi., P. Sudharto P., dan Syafrudin. "Pengelolaan Sampah Rumah Tangga Berbasis Mayarakat (Studi Kasus di Kota Yogyakarta)", dalam bttp://eprints.undip.ac.id/17210/ Diakses pada [3 April 2015].

Hamalik, Oemar. (2003). Proses Belajar Mengajar. Jakarta : Bumi Aksara.

Husein, M. Harun, (1992). Berbagai Aspek Hukum Analisis Mengenai Dampak Lingkungan. Jakarta: Bumi Aksara.

Joyce, B., Weil, M., dan Calhoun, E. (2009). Models Of Teaching. Yogyakarta: Pustaka Pelajar.

Keraf, Sony. (2010). Etika Lingkungan. Jakarta: Penerbit Buku Kompas.

Koesoema, Doni. (2011). Pendidikan Karakter : Kajian Teori dan Praktik di Sekolah. Bandung: Remaja Rosdakarya. 
M. Dahlan, Muhidin. (2000). Sosialisme Religius Suatu Jalan Keempat. Yogyakarta: Kreasi Wacana.

Majid, Abdul dan Andayani, Dian. (2012). Pendidikan Karakter Perspektif Islam. Bandung : PT. Remaja Rosda Karya.

Maksum. (1995). Mencari Ideologi Alternatif Polemik Agama Pasca Ideologi Menjelang Abad 21. Bandung: Mizan.

Martorella, P., Beal, C,. dan Bolick, C. (2005). Teaching Social Studies In Middle and Secondary Schools. $4^{\text {th }}$. US: Pearson.

Maryani, E dan Syamsuddin, Helius. (2008). Laporan Penelitian: Pengembangan Program Pembelajaran IPS untuk Meningkatkan Kompetensi Keterampilan Sosial. Bandung: Universitas Pendidikan Indonesia-tidak diterbitkan.

Maryani, E., dan Sjamsuddin, H. (2008). "Pengembangan Program Pembelajaran IPS untuk Meningkatkan Kompetensi Keterampilan Sosial”. Makalah pada Seminar Nasional, Makasar.

Samani, Muchlas dan Hariyanto. (2011). Konsep dan Model Pendidikan Karakter. Bandung: PT Remaja Rosda Karya.

Narwanti, Sri. (2013) Pendidikan Karakter Pengintegrasian 18 Nilai Pembentuk. Karakter Dalam Mata Pelajaran. Yogyakarta : Familia.

National Geographic Education Foundation and Roper ASW (National Geographic). (2002). National Geographic-Roper 2002 Global Geographic Literacy Survey [online]. Tersedia: http: \www. nationalgeographic.com/geosurvey [2 Novemver 20014]

National Geography Standards. (1994). Geography For Life. Washington, D.C.: National Geographic Research and Exploration on behalf o the American Geographical Society, Association of American Geographers, National Council for Geographic Education, and National Geographic Society.
Nisa, Jakiatin. (2010). Pengaruh Pembelajaran Kooperatif Tipe Think Pair Square Dan Tipe Numbered Heads Together Terbadap Keterampilan Sosial Peserta Didik Pada Mata Pelajaran IPS. Thesis. Bandung: SPS UPI (tidak terpublikasi).

Novarlia, Irena. (2013). Model Pembelajaran Berbasis Literasi Geografi Dalam Upaya Membangun Kecerdasan Ruang Peserta Didik. Disertasi. Bandung: SPS UPI (tidak terpublikasi).

Onwuegbuzie, A. J. and Tiddlie, C. 2003. A Framework for Analyzing Data in Mixed Methods Research dalam Tashakkori \& Teddlie (Eds). Handbook of Mixed Methods in Social and Behavioral Research, 351-384. London: Sage Publications, Inc.

Raharjo, Dawam. (1999). Islam dan Tranformasi Sosial Ekonomi, Lembaga Studi Agama dan Filsafat. Pustaka Pelajar: Yogyakarta.

Rahayu, Endang. (2009). Pembelajaran Konstruktivisme Ditinjan Dari Gaya Belajar Siswa

Sagala. (2005). Konsep dan Makna Pembelajaran. Bandung: Alfabeta.

Samani, Muchlas dan Hariyanto. (2011). Konsep dan Model Pendidikan Karakter. Bandung : Rosdakarya.

Sanjaya, W. (2006). Strategi Pembelajaran. Jakarta: Kencana.

Soekamto, Soerjono. (1990). Sosiologi Suatu Pengantar. Jakarta: Rajawali Pers.

Somantri, N. (2001). Menggagas Pembaharuan Pendidikan IPS. Bandung: Remaja Rosdakarya dan Program Pascasarjana UPI.

Sudarja, Adiwikarta. (2005). Catatan Perkuliahan Etika PLS dalam Pembangunan. PPS UPI Bandung.

Sugiyono. (2008). Metodologi Penelitian Kuantitatif, Kualitatif dan $R$ \&D. Bandung: CV. Alfabeta

Sumaatmadja, N,. (1984). Metodologi Pengajaran Ilmu Pengetabuan Sosial (IPS). Bandung: Alumni. 
Sunal, C dan Haas, M. ( 2005). Social Studies For Elementary and Middle Grades A Constructivist Approach . $2^{\text {th }}$ US : Pearson Education.

Surya, M. (2004). Psikologi Pembelajaran dan Pengajaran. Bandung: Pustaka Bani Quraisy.

Undang-Undang No. 20 Tahun 2003 Pasal 2 tentang Sistem Pendidikan Nasional.

White, Ellen G. (2005). Education Membina Pendidikan Sejati), Terj. Pasuhuk, Publishing House Bandung: Indonesia.

Wiriatmadja, R. (2002). Pendidikan Sejarab di Indonesia. Bandung: Historia Utama Press.

Wibowo, Yuni. "Bentuk-Bentuk Pembelajaran Outdoor" dalam http://staff.uny. ac.id/sites/default/files/tmp/Bentukbentuk $\% 20$ pembelajaran $\% 20$ outdoor. pdf., Diakses [3 Maret 2015].
Zubaedi. (2011). Desain Pendidikan Karakter Konsepsi dan Aplikasinya dalam Lembaga Pendidikan. Jakarta:

Zuchdi, Darmiyati. (2011). Pendidikan karakter dalam prespektif teori dan praktik. Yogyakarta: UNY Press.

Bogor Akui Limbah Industri Cemari Kali Bekasi. Tersedia: http://www.tempo.co/ $\mathrm{read} /$ news/2015/02/04/083639959/ Bogor-Akui-Limbah-Industri-CemariKali-Bekasi. Diakses [20 Januari 2015].

BPLHD limpahkan kasus kejahatan lingkungan. (2014). Tersedia: http://radarbandung. co.id/berita--bplhd-limpahkan-kasuskejahatan-lingkungan-.html. Diakses [20 Januari 2015]. 